$$
\begin{array}{cc}
E & E \\
\sum_{0} & 160 \\
0 & W 3
\end{array}
$$




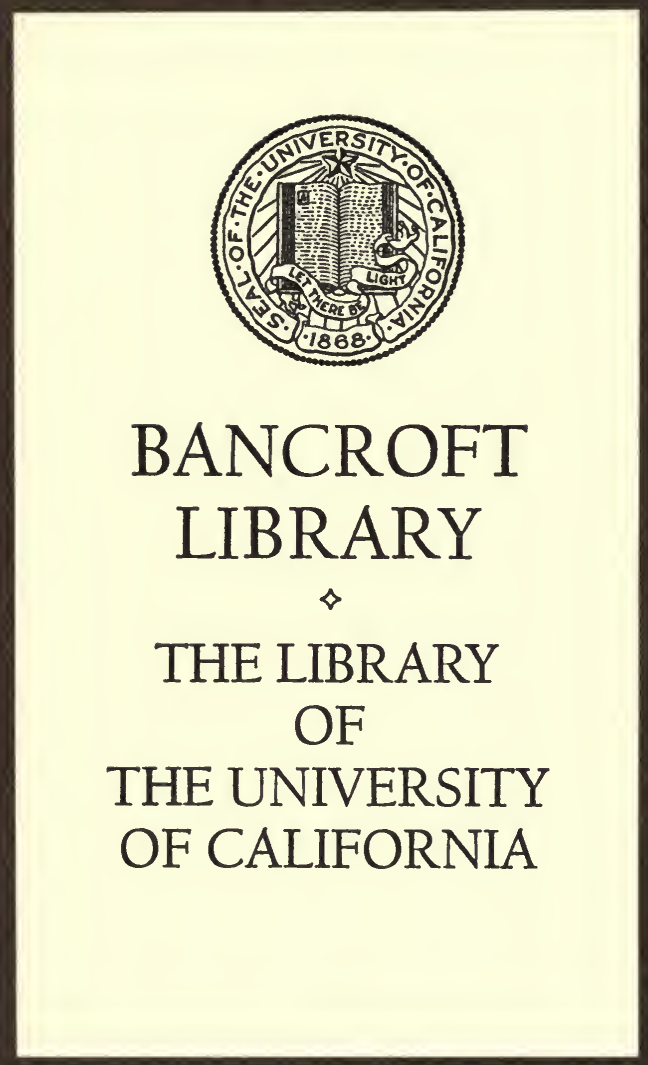




\title{
Recreation Uses on the National Forests
}

\author{
By \\ FRANK A. WAUGH \\ Collaborator
}

1918

U. S. Department of Agriculture

Forest Service 


\section{E160 \\ W3}

Digitized by the Internet Archive in 2007 with funding from Microsoft Corporation 


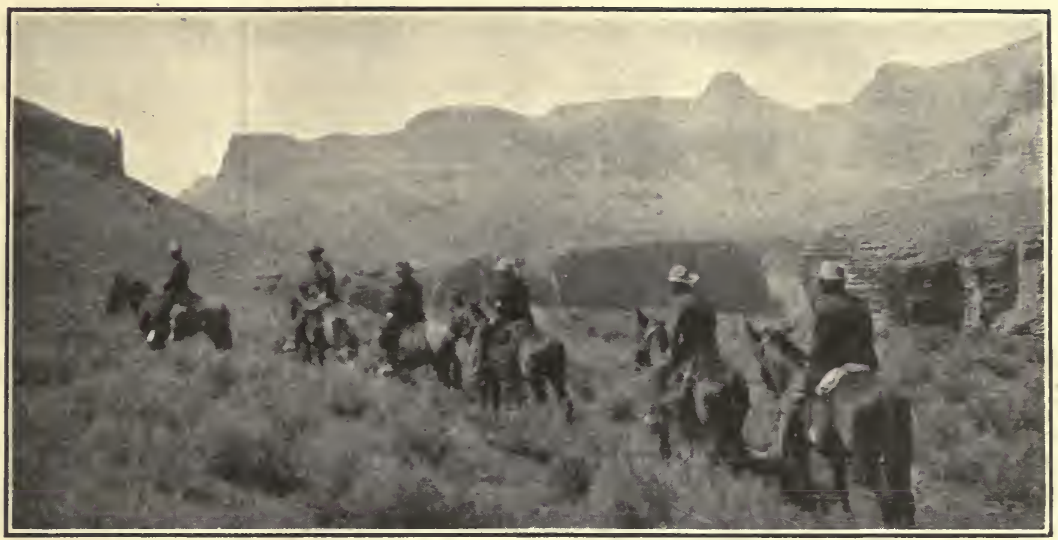

On the Tonto Trail in the Grand Canyon

\section{Recreation Uses on the National Forests}

ONG before the National Forests were established men went Lunting in the woods and fishing in the streams. Camping and picnicking in the wilds had an ancient priority over the administration of those same areas by the Federal Government for the, production of timber and the conservation of water. These conditions were not changed by the assignment of the lands to the care of the National Forest Service, except that such recreation uses were multiplied and intensified.

It is of course inevitable that the Forests should be so used. Outdoor recreation is a necessity of civilized life, and as civilization becomes more intensive the demand grows keener. The vast extent of our present National Forests, their enticing wildness, and the notable beauty of the native landscape lure men and women thither by hundreds of thousands. The really enormous extent and value of this kind of forest product has been generally overlooked in America. 
This oversight, however, is only local and temporary. In older countries, where public forests have existed for centuries, the recreation use of such areas has always been recognized. It would be perfectly easy to show that recreation was, in fact, the original and primary purpose in the creation of public forests. The ancient law of England is most significant on this point. From before Norman days until the reign of Charles II the legal definition of a forest stood as follows:

A certain territorie of wooddy grounds and fruitfull pasture, priviledged for wild beastes and foules of Forest Chase and Warren to rest and abide in, in the safe protection of the King, for his princely delight and pleasure, which territorie of ground, so priviledged, is meered and bounded with irremoueable markes, meres, and boundaries, wether knowen by matter of record or else by prescription. ${ }^{1}$

Passing from ancient law in England to present conditions in the United States of America, we find that recreation uses on the National Forests are rapidly increasing, and that they have reached a stage where more definite and systematic provision must be made for them in the plan of administration. In view of this situation, the Forester, early in 1917 , commissioned the writer to make an extended examination in the field and to report to him as to existing conditions of recreation, with recommendations of methods and general policies.

The present report is based on a five months' field study of existing conditions. Visits were made to all the Forest districts, and to a considerable number of individual Forests. Special attention was naturally given to those regions where recreational developments appear to be most pressing. In this way it was possible to hold extended consultations with Forest officers having supervision of the lands thus used, and also with those private citizens who are using them.

It should be said that the point of view of the writer is that of the professional landscape engineer. From this standpoint the 
landscape of the wide Forest areas has very great esthetic and human value. The mountains, glaciers, lakes, streams, woods, and natural parks contribute largely and effectively to human health and enjoyment. This contribution has a demonstrable value. The fundamental problem of the landscape engineer would then be to release these values, to make the human resources of the Forests accessible to visitors, and not merely accessible but intelligible and effective.

The moment that recreation (using this word in a very liberal meaning) is recognized as a legitimate Forest utility the way is opened for a more intelligent administration of the National Forests. Recreation then takes its proper place along with all other utilities. In each particular case these utilities are weighed against one another and a plan of administration devised to adjust and harmonize, to the utmost point practicable, the various forms of use so that the largest net total of public good may be secured. Where one must be subordinated to another, preference is given to that of highest value to the public.

With these general considerations in mind we may take a look at the National Forests, observing the extent and nature of current recreation activities.

The simplest form of recreation is found in hiking, packing, or automobiling through the Forests. There have already been provided for administrative uses (fire protection, etc.), thousands of miles of trails. These are built to standExisting Recre- ardized specifications, the most popular type ation Uses. ("Class A trails") providing for a safe, clean footway, 4 feet wide, laid at a maximum gradient of 6 per cent. Admirable examples of this kind of trail were examined in the Natural Bridge Area of the Appalachian Forest in Virginia. Here, in a mountain country readily accessible to the large eastern centers of population, these trails lead through splendid forests with inspiring landscape outlooks, across 


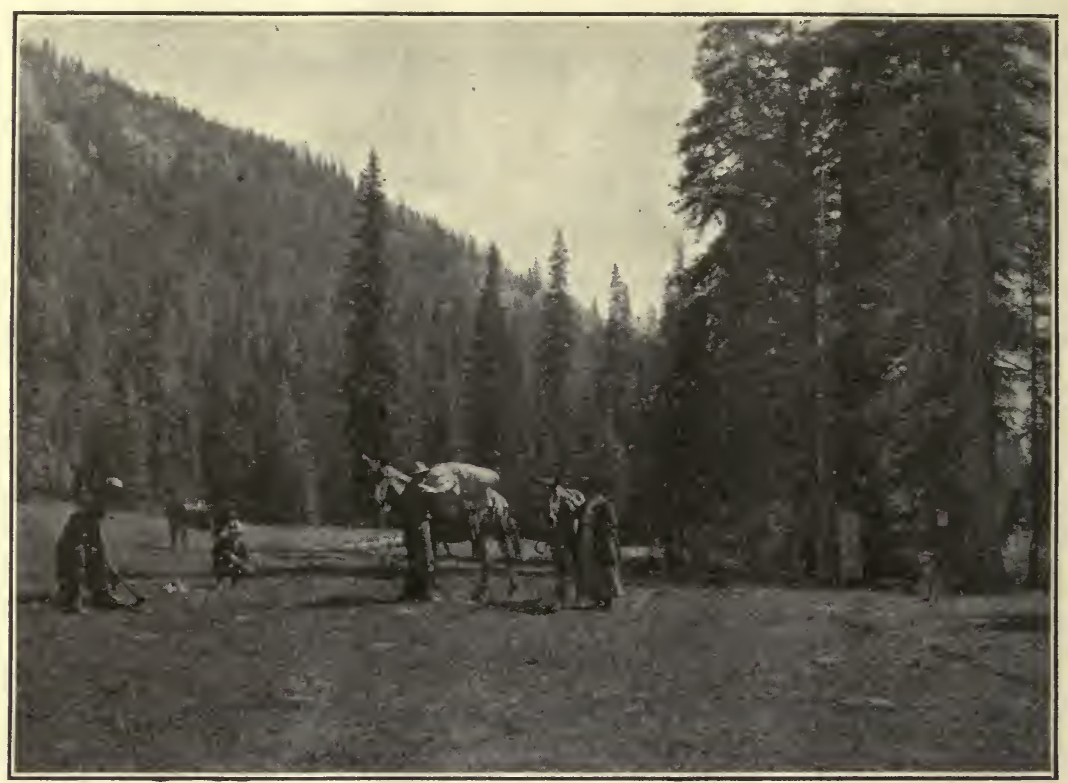

A camping party in the Uncompahgre National Forest. Forest Service fire tool box under tree on right

delightful streams and amidst surroundings well adapted to camping and all the more rigorous forms of outdoor exploration.

Yet this is merely a sample. Similar trails by hundreds of miles are found in the Forests of Colorado, California, Oregon, Washington, Montana, and indeed wherever the Forest Service has established its administration.

Besides these trails, suitable for foot passengers and pack animals, there are within the Forests other hundreds of miles of roadway fit for wagon traffic and for automobiling. Much of this mileage has been built by the Forest Service, usually in cooperation with local (county or State) authorities. But, however financed, the finished roads lie far and tempting through the Forests. Thither the camper in his wagon and the tourist in his automobile take their way, and here they linger for days and weeks at a time. The mountains, streams, and woodlands are laid open to thousands of persons in this way, and no one counting 
their crowding procession can doubt their appreciation of the opportunity.

A typical example of this provision for public service is found in the "Park-to-Park Highway" running between the Yellowstone National Park and Glacier National Park, constructed by Forest engineers and passing over the Great Divide and through the Beaverhead and the Bitterroot Forests. The most famous example is certainly the Columbia River Highway which, though not designed or built by the Forest Service, passes for miles through the Oregon National Forest.

Along these automobile and wagon trails camps are in strong demand. Many trail tourists do not mind patAutomobile ronizing the hotels a part of the time, but for Camps the rest they greatly prefer the tent and the camp fire. To meet their needs the Forest Service has laid out and equipped a large number of camps. These are always located where good water is available, and usually a

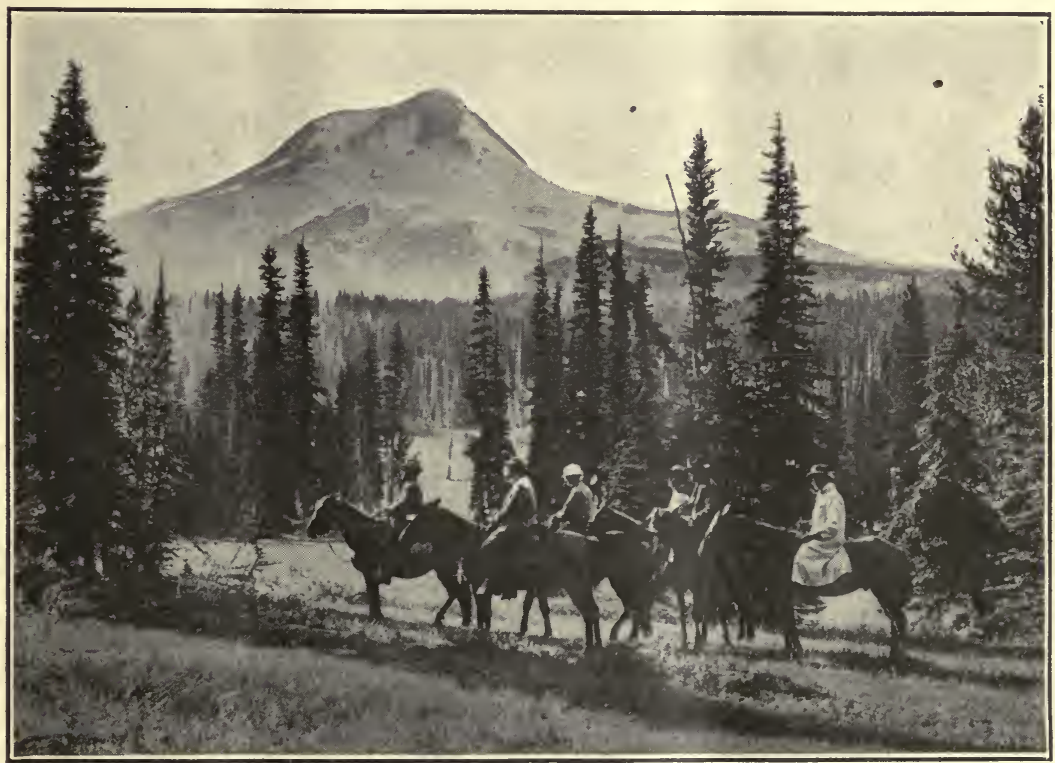

Mount Hood from a timbered park in the Oregon National Forest 


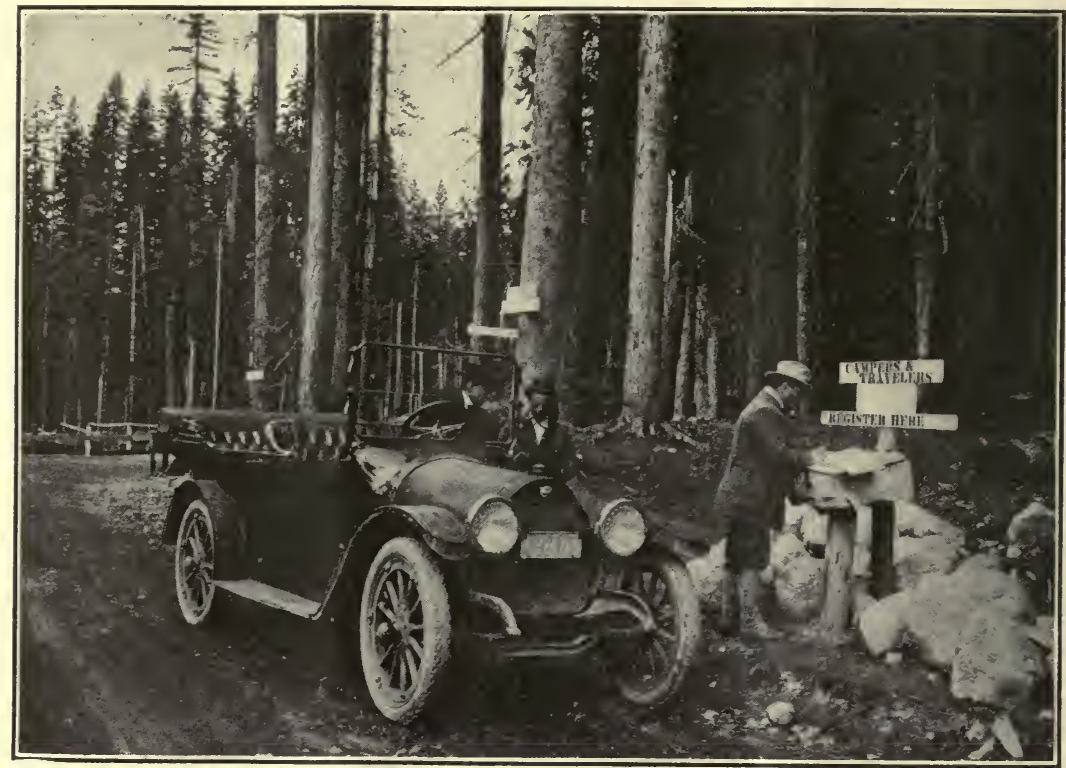

National Forest visitor registering his name, address, and destination. Wenatchee National Forest.

(Sunset Highway).

practicable wood supply is an item of the equipment. Simple provisions are made for sanitation, and cement fireplaces are often installed. Sometimes telephone service is made available. Such camps are extensively used by travelers, especially along the more popular through routes. To a certain degree they prove a protection for the Forests, since the camp fires of the tourists, instead of being set in out-of-the-way and dangerous places, are made in safe areas. It is found, moreover, that the the campers, once their interest and cooperation is aroused, become a volunteer fire guard of no mean efficiency. In hundreds of instances these tourists report incipient fires or assist in putting them out.

On the forest areas are many spots which,

Picnic

Grounds for special local reasons, have come to be popular as picnic grounds. The Big Hole battle field, near Wisdom, Mont., is a fair example. Here the old settlers hold an annual reunion, and parties congregate at other times. 
Probably the most notable example of this form of recreation is found at Eagle Creek on the Oregon Forest, on the Columbia River Highway. Here the mountains open to the picturesque Eagle Creek gorge, through which a beautiful mountain stream flows down from the snows of Mount Hood. At the mouth of the stream, where it is crossed by the Columbia River Highway, the canyon widens into a small natural park surrounded by big trees. This spot is approximately 40 miles east of Portland, just the convenient distance to make an acceptable stopping place for automobiles running out from the city. Here the Forest Service has installed sanitary conveniences, a good water supply, a number of fireplaces, and picnic tables, with certain other practical accommodations for campers.

And here the picnickers come literally by the thousands. On any pleasant Sunday in summer every table and camp fire is crowded and the grounds take on the appearance of circus day.

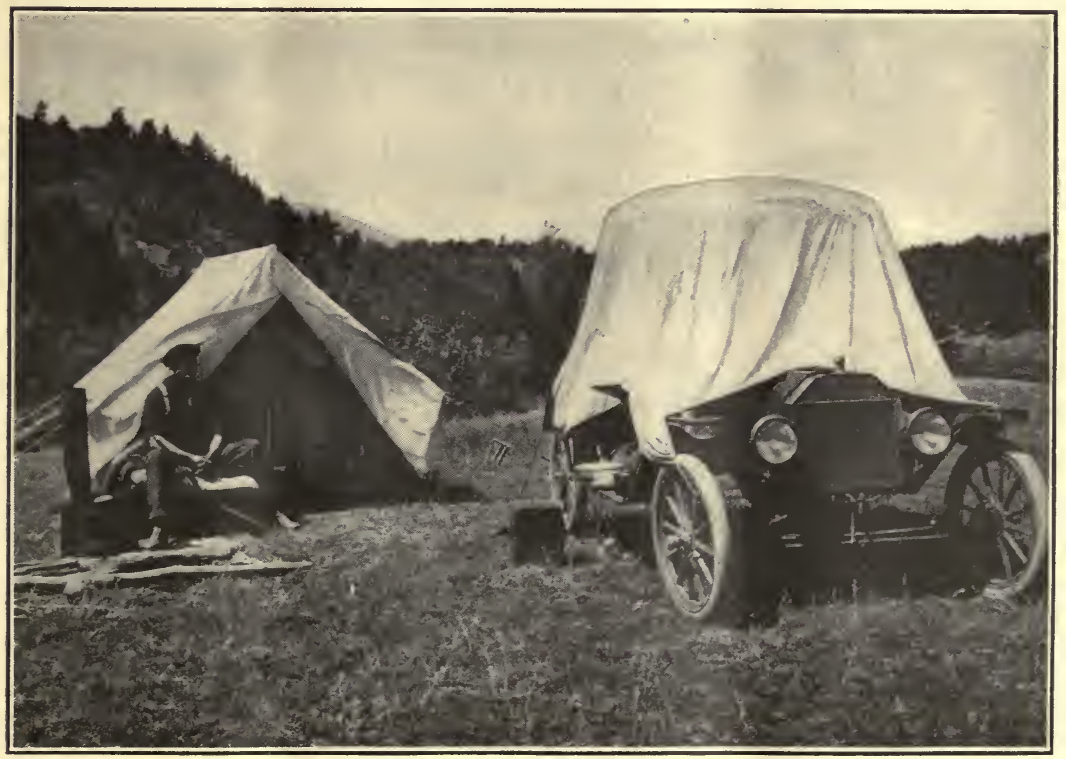

$75062^{\circ}-18-2$

An automobile camper in the Pike National Forest 
Hunting and fishing are perhaps the sports most typically associated with the Forests. In the great public forests of the Old World the rearing of game for food is often

Game

Preservation practiced on a large scale. The propriety of using our National Forests to multiply game for sport, for food, or for its own sake seems obvious. To these problems the Forest Service has already given considerable study. Specialists from the United States Biological Survey have also assisted materially in this field.

Several large areas within the National Forests have been set aside through State legislation and Federal proclamation as game sanctuaries. In these areas various species of wild fowl, deer, elk, and bison are protected at all times. Hundreds of square miles adjoining the Yellowstone National Park are reserved in this way for the pasturage and protection of the elk. In the Wichita Mountains of Oklahoma is a very successful preserve devoted especially to the buffalo. Here there is a considerable herd of these animals, and they are thriving and multiplying in a very satisfactory manner.

Forest officers everywhere cooperate with other Federal officials and with State and local authorities in stocking streams with trout or lakes with other fish and in their protection under State game laws. Indeed it is almost the rule that the local forest rangers shall be also State game wardens and shall assist everywhere in the enforcement of game laws.

Some of the noblest landscape in the wide world is to be found within the National Forests. No argument is

\section{Scenic}

Reservations required to show that where such landscapes can be preserved for human use without sacrifice of other interests they should be firmly protected. And if in special areas this direct human value of the landscape can be shown to outweigh other economic 
values it obviously becomes good public policy to sacrifice the lesser interest to the greater.

Actually this is the situation which arises in many restricted areas. In the White Mountains of New Hampshire, for example, are a number of very beautiful neighborhoods the charm of which could be quickly annihilated by heedless stripping of the forests. These specific localities have a high recreation value enjoyed by thousands of persons annually-a value immeasurably greater than that to be reaped from a sale of the lumber. The preservation of such tracts for their purely scenic and recreational values seems hardly open to debate. The only questions are just what areas must be preserved for their landscape beauty, how they shall be defined, and how they shall be managed to secure their largest contribution to the beauty of the landscape. An early study should be made in the White Mountain Forest to determine these very matters.

There are hundreds of areas within the National Forests where similar reservations should be made for the same ends and on the basis of similar investigations. One other outstanding example deserves special mention. This is the scenery of Lake Chelan in central Washington. Here we have an ancient glacial gorge now dammed by the moraine at its mouth and filled with the deep blue waters of many glaciers. These glaciers hanging on the steep alpine heights which shut in the lake are reflected, along with the white rolling clouds upon the mountain summits, in the glassy waters below. If one had the wildest fjord of Norway brought inland and filled with sweet and quiet waters, or if one had Lake Brienz of Switzerland extended to a length of 50 miles, one would have a possible competitor for Lake Chelan; but until such improvements in terrestrial topography can be made this lake is unique. It is in short, and without exaggeration or qualification, one of the best landscapes in the world. 


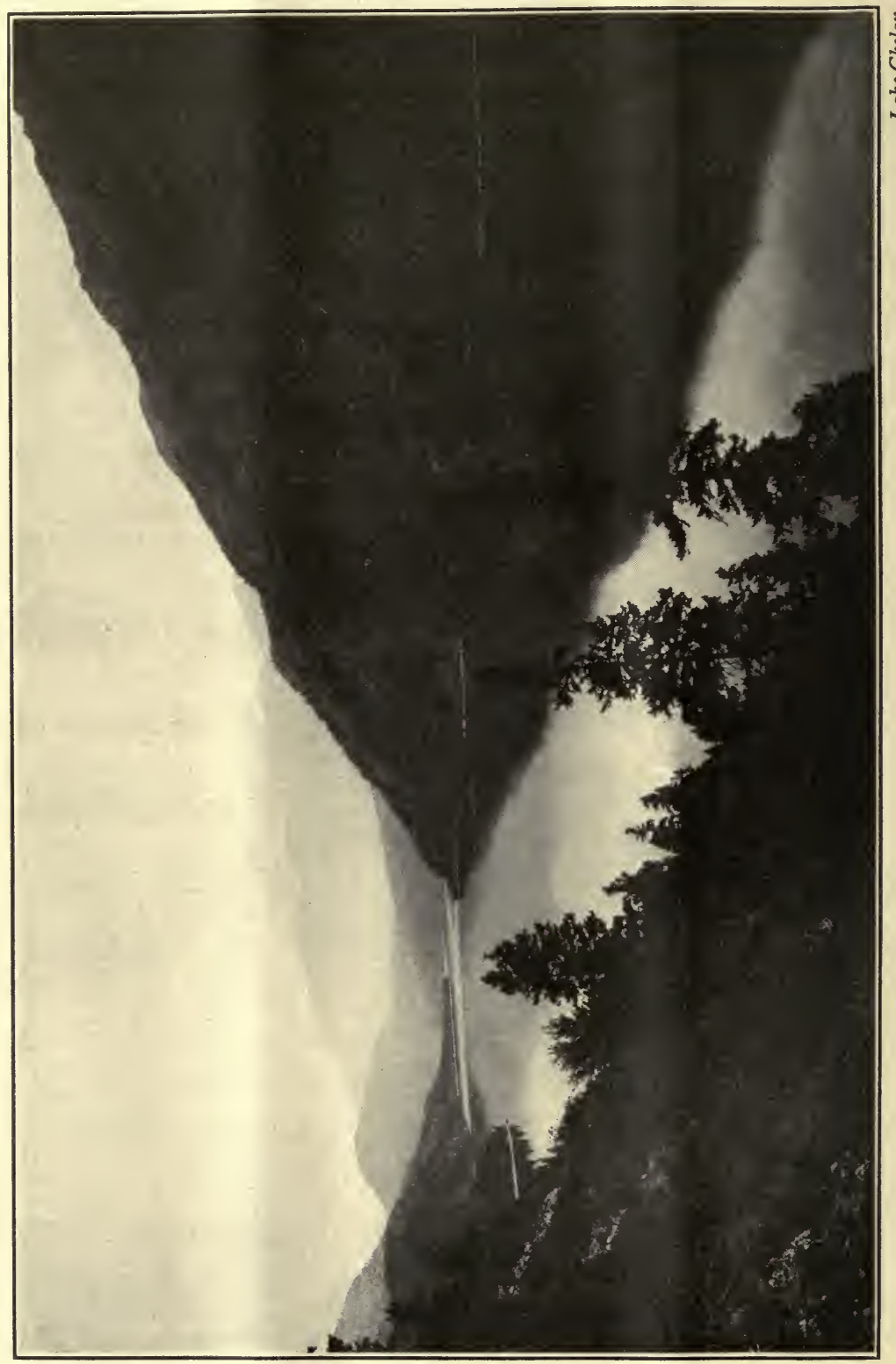


Fortunately a large proportion of the shores and of the adjoining country belongs to the public and rests under the administration cf the Forest Service. Fortunately, too, these immeasurable scenic values can be preserved without the slightest interference with the timber values or with the greater grazing interests in this territory. Here everything is to be gained and nothing lost by a frank recognition of esthetic values and an administration based on the policy of making all utilities (lumbering, grazing, irrigation, watershed protection, mining, and landscape beauty) fully available to the citizens of the entire country.

In our scheme of legislation and administration the National Monuments are frankly a makeshift. The man in the road finds the idea a puzzle. Let it be explained thereThe National fore that each National Monument is created Monuments presumably for the preservation of some natural wonder or some historic or prehistoric relic. The land including the objects to be preserved is withdrawn from the usual status of public lands. It can not be taken up for private use either as farm homesteads or for mining or other similar commercial uses. It is closed to commercial exploitation. This withdrawal is made by presidential proclamation, and herein lies an important difference between a National Monument and a National Park, which can be created only by act of Congress.

Here is another inconsistency which troubles the average man, in that some of the National Monuments are administered by the Department of the Interior while others are under the management of the Department of Agriculture, and two are under the authority of the War Department. The practical explanation of this discrepancy is to be found in the fact that some of the Monuments were erected out of lands already under administration of the Department of Agriculture as National Forests, and the 


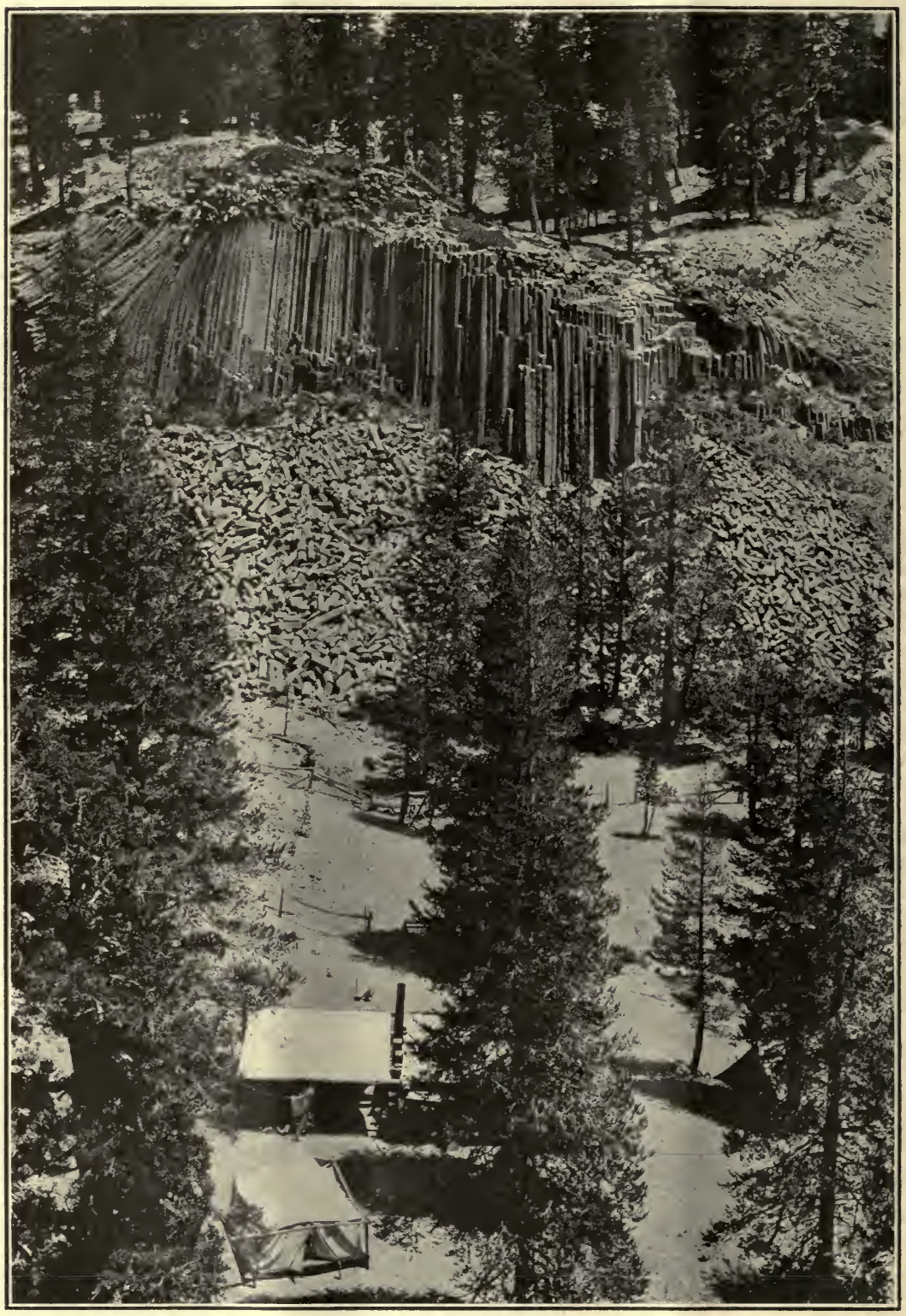




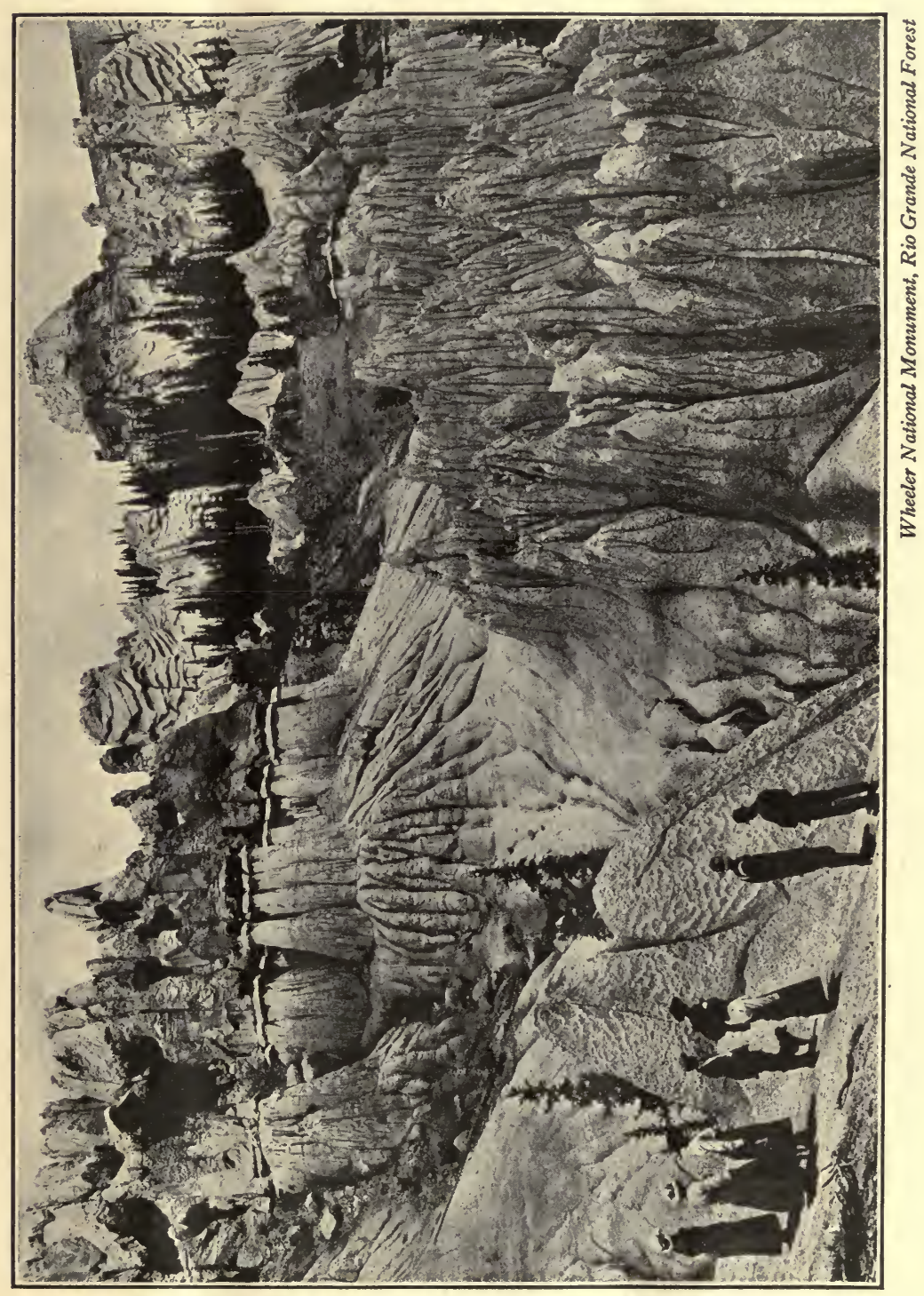


proclamations which altered the status of the lands did not disturb the existing administration of those lands. It was more simple and economical to leave the care of these areas in the hands of the men already in charge, with an organization on the ground which had to be maintained in any case.

On the other hand, some National Monuments were established from other lands in the hands of the Department of the Interior; and in these cases likewise the status of the land was changed without affecting the administrative authority.

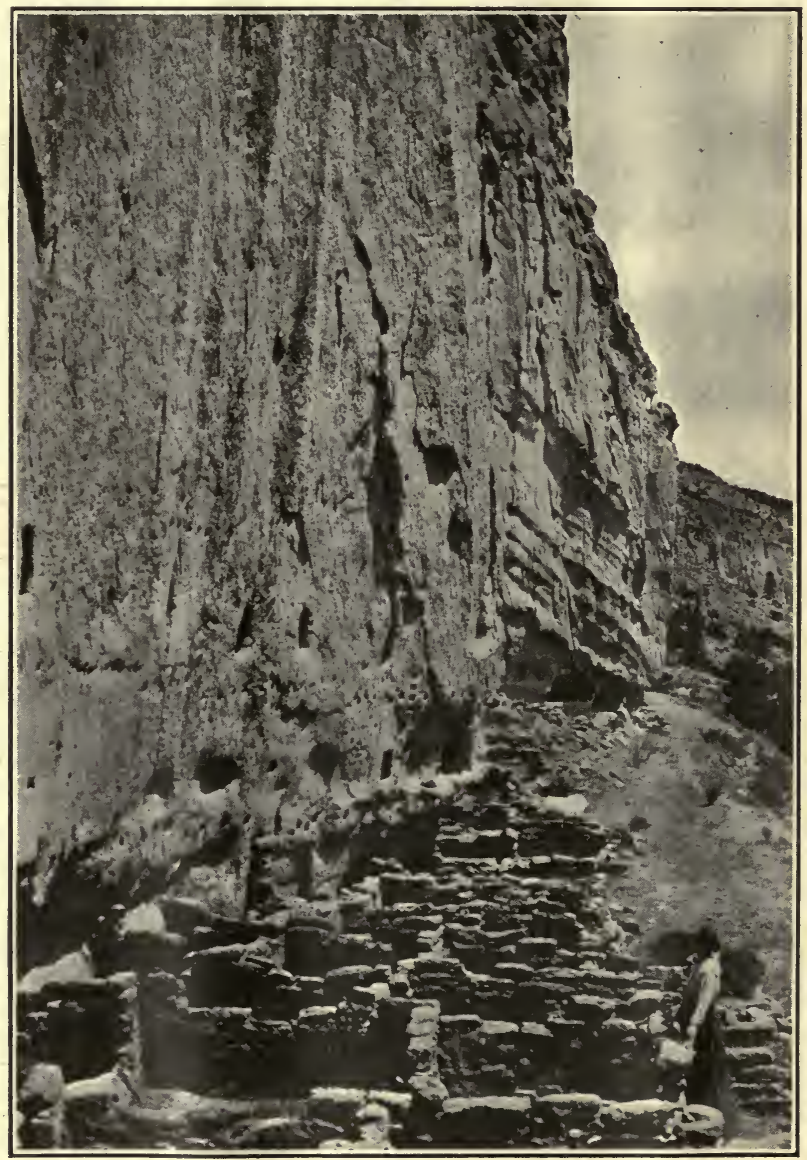

Old cliff dwellings, Bandelier National Monument, Santa Fe National Forest 
In this way the Forest Service finds itself charged with the administration of a number of areas from which the usual commercial utilities have been excluded by law and which have been specifically reserved for recreational and allied purposes. ${ }^{1}$

One of these National Monuments stands so clearly in a class by itself that a special word should be given to it here. This is the Grand Canyon of the Colorado in northern

The Grand Canyon

Arizona. By consent of the civilized world this stands enrolled as one of the foremost wonders of creation. It exhibits beyond all dispute those qualities which have thus far generally controlled in the making of our National Parks. The propriety of including the Grand Canyon in our National Park family is so overwhelming that no objection could be raised against it, if indeed anybody were disposed to raise such objection.

Yet in the natural course of legislation and executive procedure the Grand Canyon has become, not a National Park, but a National Monument, and the Forest Service has been charged with its protection and administration. And the Forest Service must obviously do the best it can, not to make a Forest of the Grand Canyon, but to manage it as a National Monument.

At Fresno, Cal., is located a State normal school. This school, desiring to maintain a summer session, but finding the midsum-

\section{Cooperation} with Institutions. mer climate at Fresno inconvenient, has arranged to hold such summer sessions at Lake Huntington, about 75 miles back in the mountians. Here in a glorious black forest, beside a cool glacier-fed lake and almost within reach of the perennial snows, the normal school is building up a permanent equipment of dormitories, classrooms, and laboratories. This development

\footnotetext{
${ }_{1}$ A list of the National Monuments now under the administration of the Forest Service is given in an appendix.
}

$75062^{\circ}-18-3$ 


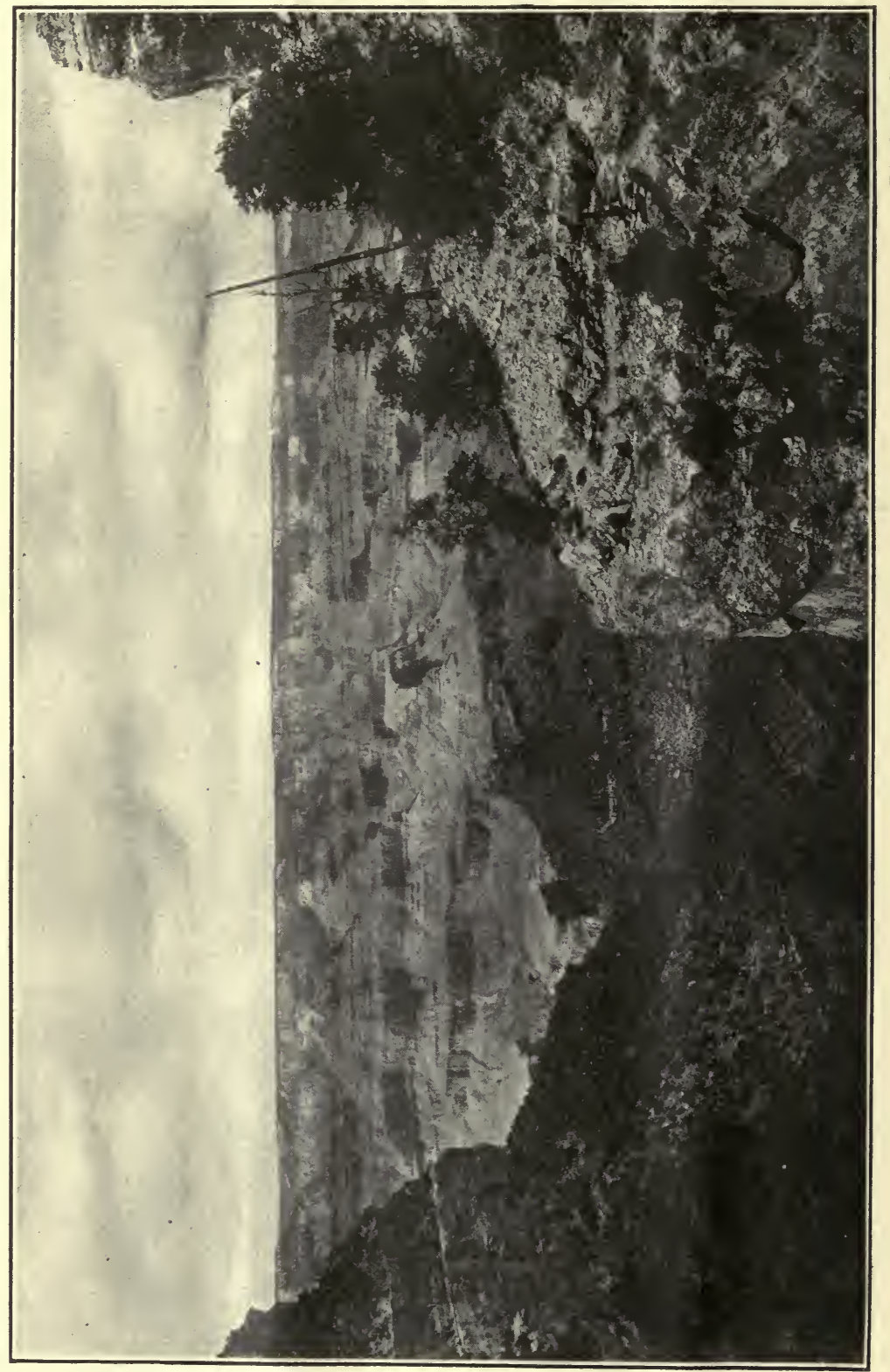


is going forward on land leased in one of the National Forests. The active cooperation of the Forest Service has from the first been an essential factor in this undertaking.

At other points on the lands of the National Forests other institutions of various characters have developed, the ground being held under liberal leases. In this list should be included schools, sanatoria, fraternal camps, summer resorts, etc.

Perhaps the most interesting of all recreational developments on the National Forests is to be seen in the municipal playgrounds. The first and most fully developed of these is

\section{Municipal} the one established by the city of Los Angeles, Playgrounds Cal., on Seeley Creek Flats in the Angeles National Forest. Here the city leased from the Forest Service a tract of 23 acres of well-wooded mountain land beside a pleasant stream and lying at an elevation of 3,500 feet. On this tract they have erected 6i small summer bungalows, each capable of accommodating from two to six persons. These are furnished with cot beds. A central clubhouse has been built; also a central kitchen with a pleasant outdoor dining room. Water supply, sanitary equipment, cement swimming pool, tennis courts, and other simple camp facilities have been provided. When in full swing the camp will take care of about 300 persons.

This camp is under the management of the Los Angeles Playground Commission, and is run as a part of the city playground system. Citizens of Los Angeles who wish to take a vacation in the mountain forests register with the playground commission and are sent out in relays for terms of two weeks. Some classification of vacationists is made. For example, the first two weeks of the season the camp will be open to families, the second two weeks to boys' clubs, the third fortnight to women and girls' clubs, etc. Members of the regular trained playground staff are 


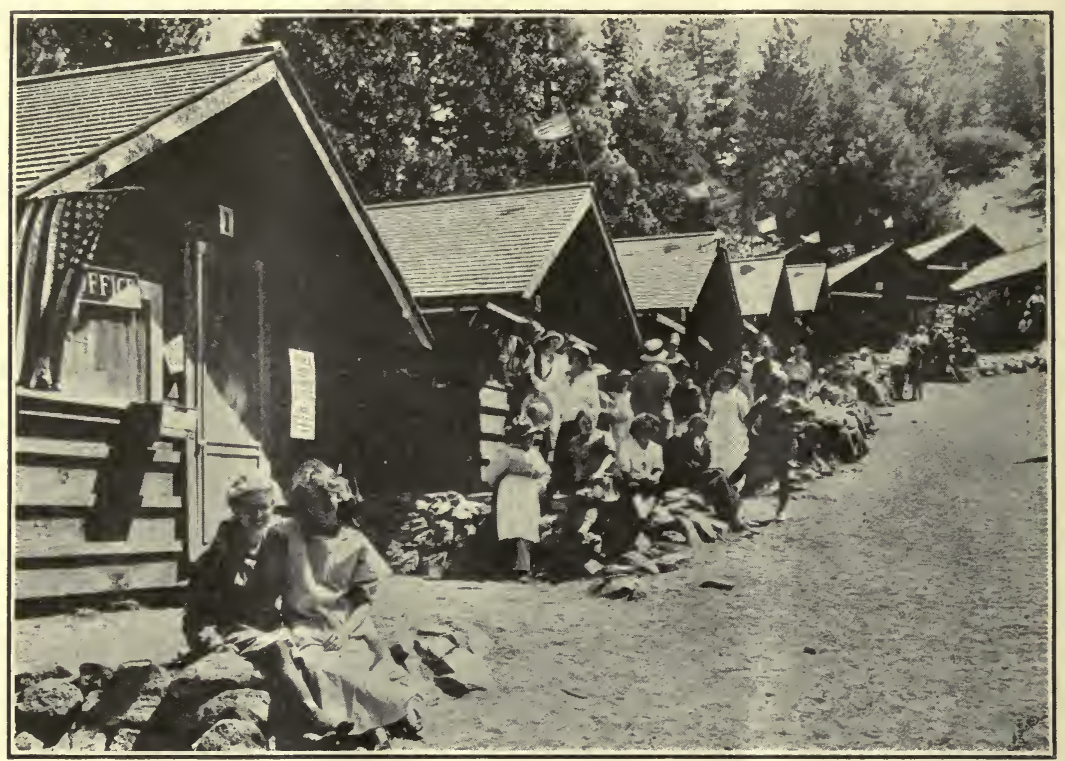

Los Angeles Municipal Camp, Angeles National Forest

on hand to direct the work of the camp. . Each camper is expected to help with the necessary camp work, which averages something less than one hour's labor a day. The bungalows, beds, and food are supplied by the city; also transportation by rail and automobile from Los Angeles to the camp (about 85 miles) and return. 'This entire two weeks' vacation, house, food, and transportation, costs, under war conditions of I9I7, \$8.50 per person. After participating personally in the camp of I9I7 I can testify that the accommodations are clean and comfortable, the food wholesome and abundant, the surroundings delightful; and I am reliably informed that the city had a balance of profit left at the close of the year's operations.

Several other cities have taken leases on other Forest tracts for similar use, so that this form of municipally directed recreation bids fair to reach a considerable popularity. 
A great many persons prefer to do their summer camping in comfortable cabins of their own building. These they like

Permanent Camps to own. Under special legislation designed to meet this need the Forest Service now leases small tracts (one-fourth acre to I acre) to such persons on terms which make it feasible for them to build and furnish their own camp houses. Naturally, these camps are.gregarious, both because most campers like a little society, even in the woods, and because the attractions of pleasant streams or lakes appeal to many persons alike.

The obvious tendency therefore is to develop this important type of forest recreation in the form of small summer colonies, usually upon streams or lakes. Several hundred such centers have already been established. These are pretty well distributed over the entire National Forest domain. The most intensively developed are those in the Angeles Forest north of

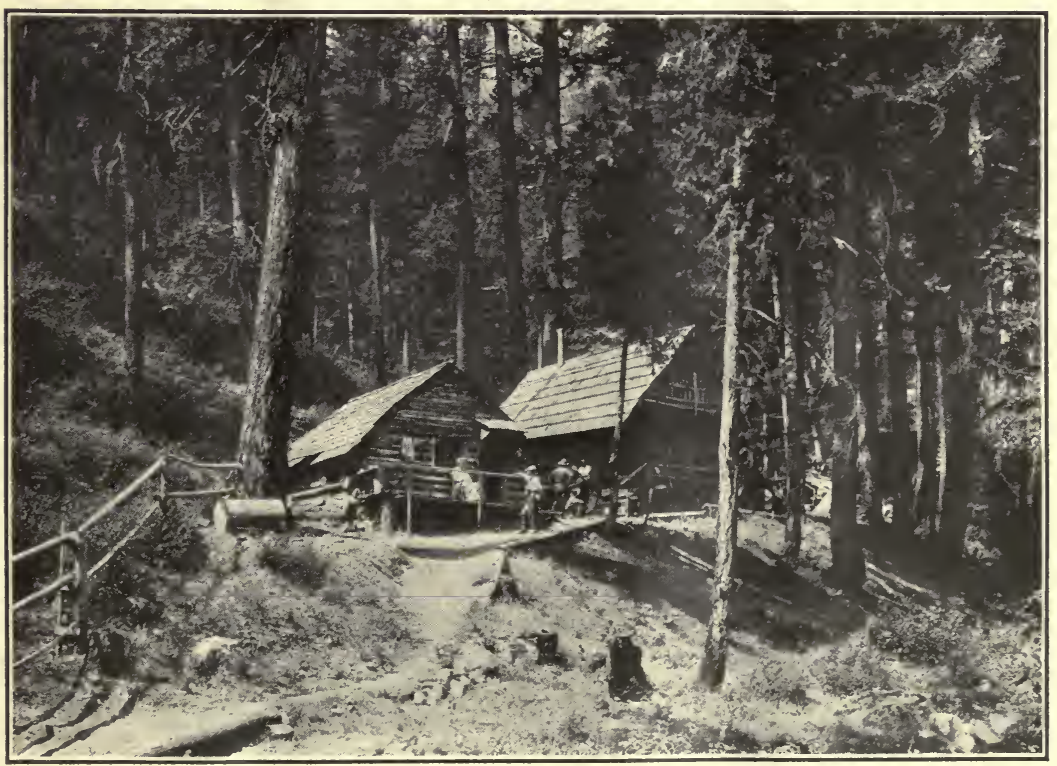

A summer camp in the Shasta National Forest 
Los Angeles, Cal., where every canyon which has running water is crowded full of camp houses, many of them substantial and well furnished and occupied for several months of the year.

Indeed some of these colonies readily pass from the character of summer camps to the condition of permanent towns. At Cascada, Cal., where there is now a railroad Permanent terminus serving an active lumber industry, Communities a large and permanent hydroelectric development, and a growing vacation clientele, the town shows every assurance of permanence. Yet it is all built upon the land of the Sierra National Forest, not a foot of which can be patented. Every building, every street, and every public utility of every sort exists upon a revocable permit granted by the Forest Service. . It is true that, at some future time if the development of Cascada continues, the territory may be eliminated from the Forest and the town thrown on its own resources, the land may be deeded to individuals, and all the usual agencies of local government set in operation; but by that time the physical form of the town will be largely fixedfor better or for worse.

One other specific example out of many deserves separate mention. In the Cleveland Forest, at an elevation of about I mile, is a tract of land covering several thousand acres and possessing a somewhat remarkable landscape beauty. There is a good forest cover, mostly of yellow pine and black oak; there are numberless grassy natural parks; there are many springs of sweet water, running brooks, and two attractive little lakes.

This tract lies about halfway between San Diego on the west and the Imperial Valley on the east, and is accessible by automobile over a good road recently constructed by Forest Service engineers. This road connects with a new State road between 
San Diego and E1 Centro. Now the Imperial Valley, though highly prosperous agriculturally, does not enjoy a salubrious summer climate. Rather is it noteworthy for its aridity and its consistent warmth. The citizens therefore, living below sea level, look longingly to the mile-high mountains, 70 miles away on their western horizon, where great trees give benevolent shade, where brooks of sweet water run singing over the stones, and where quiet lakes reflect the dark shadows of the pines. On the good roads now provided, these delectable heights can be reached by automobile in three or four hours. Is it any wonder that the dwellers in the hot valley should covet these well-watered mountains as a place of summer residence? Many of the people of San Diego, to whom the tract is equally accessible, would likewise be well served by summer homes on these same mountains.

Apparently these plain needs can be fully met in the Cleveland Forest without the slightest sacrifice of other Forest utilities. This means, however, the development of a practically permanent community on virgin land. Streets must be laid out, lots surveyed, water supply protected, sanitary precautions insured, and provision made for public buildings, playgrounds, and all equipment of a full-fledged and active community. In short, we have here presented a most fascinating problem in town planning.

Having now enumerated the principal forms which recreation assumes on the National Forests, and having in view the question as to what policies should prevail in the adminValuation of istration of these interests, it seems desirable Recreation to form the clearest possible conception of the extent and value of this recreation.

In the summer of 1916 forest officers in the field were directed to report upon the number of recreation visitors with a rough classification of their activities-camping, fishing, hunting, motor- 
ing, hiking, etc. As the investigation was new, the specifications somewhat vague, and the census officers were preoccupied with other duties, the results when compiled could not be too freely accepted as decisive. Personal examination convinces me that the numbers reported were generally too low. Nevertheless, the summary figures indicated that approximately two and a half million persons during the summer of 1916 entered upon the National Forests for some kind of recreation. ${ }^{1}$ During the summer of 1917 the census, which it had been planned to continue, was seriously impaired through the depletion of the Forest staff by enlistment in the Army. However, a certain number of Forests were able to report the count of recreation visitors for the year, and these reports indicate very clearly a substantial increase over the year 1916. A conservative estimate for 1917 would place the total of recreation visitors at $3,000,000$.

If these figures seem large it must be remembered that the National Forests are large. They cover three and one-half times the area of all New England. There are ${ }_{5}$ I different Forests, with an area of about $156,000,000$ acres, occupying territory in 22 different States and Territories.

A further estimate made by the forest officers on the ground indicates that the average stay of these visitors was two and onehalf days. This gives us a basis for a more accurate measurement of the total recreation product, since students of this subject generally agree that the hour is the proper unit by which to measure recreation. If, then, the average visitor spent two and one-half days on the Forests, and if we call these ro-hour days, thus converting the time per person to 25 hours; and if we multiply this factor by the number of visitors $(3,000,000)$ we reach the considerable total of $75,000,000$ recreation hours. While the factors

\footnotetext{
${ }^{1}$ It scems probable that in these totals a good many individuals were counted twice. Thus a single person might pass through ro different Forests and be separately counted in each of them. 'This fact, however, does not affect our computation.
} 
here used are all estimates, they are carefully made upon actual counts, and the final product is not far from the truth.

The further matter as to the market value of this body of recreation can be determined within reasonable limits. Mr. G. A. Parker, superintendent of parks in Hartford, Conn., the recognized authority on such matters, computes that park recreation as managed in the United States costs on the average 2 cents an hour. This, however, is cost, not value.

The human value of an hour spent in skating in a city park or fishing in a National Forest would be hard to estimate; but ultimate human values are seldom estimated in dollars and cents. Our usual figures indicate merely commercial values, i. e., market prices. Now the commercial value or market price of recreation is determinable quite as easily and exactly as the price of beans or books or tobacco. Enormous quantities of recreation are daily bought and sold in the open market, and the prices are as well recognized as for any commodity of commerce. The movies cost Io cents or I 5 cents; the vaudeville theaters cost 25 cents or 50 cents; the "legitimate drama" costs 50 cents to $\$ 2$ a hearing; concerts cost from 25 cents to $\$ 2$; grand opera, $\$ 2$ to $\$ 5$; a baseball game costs 50 cents; the circus costs 50 cents for the big tent, Io cents for the concert, and ro cents for the side show.

A moment's thought will show that 5 cents an hour represents the absolutely minimum cost of commercialized recreation. In some towns a person can buy the mild entertainment of an hour's ride on the street cars for a nickel. There still are streets where the movies perform indescribable rubbish for 5 cents.

On the whole, however, it is perfectly clear that very few and very questionable forms of recreation are offered at the price of 5 cents an hour. If we go up to ro cents an hour the availabilities improve. The movies are better; we can occasionally get into a skating rink for a dime; we can buy an hour's reading in a cheap 
magazine; we can ride out to the park and back; or we can get Io cents' worth of fishhooks and go fishing. Our choice is still much restricted.

If we seek a comparison with forms of recreation more nearly like those offered by the Forests, our results are less precise but no less convincing. A few men are able to maintain private hunting and fishing clubs in the Adirondacks, in Maine, or on the Restigouche. The time they pass at these resorts costs them anywhere from \$I to \$IO an hour. To take a vacation at any public seaside or mountain resort costs from $\$ 2$ to $\$$ Io a day.

These figures, though somewhat sketchy, are a statement of plain facts. In view of them the following generalizations are self-evident:

I. The minimum market cost to the consumer of wholesome recreation privately provided is ro cents an hour.

2. The average cost of commercial recreation is much higher, probably lying somewhere between 25 cents and \$I an hour.

It ought to be self-evident, further, that the great bulk of such recreation is worth all it costs. If it isn't, the large majority of our whole population are being daily robbed in their recreation bills. One more premise hardly needs an argument, viz, that the average recreation on the National Forests is as valuable in all human ways as the average of commercial recreations.

Now if we take even the minimum of these estimates and apply the figures to the problem in hand the results are fairly sobering. For 75,000,000 recreation hours annually yielded by the National Forests (and these figures will be quickly and widely exceeded in years to come), valued at the minimum of ro cents an hour, amounts to $\$ 7,500,000$ - a pretty penny.

Stated in general terms it appears that the recreation use of the National Forests has a very substantial commercial value, and that recreation stands clearly as one of the major Forest utilities. 
We have seen the wide extent and variety of recreation uses on the National Forests, and we have considered briefly the commer-

\section{General Policies}

cial value of this product. We are now in a position to discuss some of the questions of public policy as implied in these data. Such questions of policy must inevitably have a considerable influence on the practical administrative operations of the Forest Service.

It would seem that the following principles may be safely adopted:

I. Recreation upon the Forest areas is a social utility of large dimensions and very substantial value.

2. Recreation of many kinds, all legitimate, develops on practically all areas of the National Forests. It is inherent in the character of the Forests and must be recognized as a permanent and universal factor in Forest administration. Only by the most drastic and extraordinary administrative measures could recreation be excluded from particular Forest areas.

3. Being a public utility of great value and being inevitable to the Forest administration, recreation should be developed by the Forest Service on the same basis as any other Forest utility.

The most logical statement of the situation is made by saying that recreation stands on a par with other major uses of the Forest areas, and is to be managed on its merits precisely like the others. These major uses are-

Timber production

Grazing.

Watershed protection.

Recreation.

And from the figures given it would appear that recreation is by no means an unworthy member of this group.

Now the policy with respect to handling these several utilities on the Forest areas has never been obscure. Where two or more of 
these main uses can be served at the same time on the same area they are carried forward side by side, sometimes in actual cooperation. Whenever two of these uses come into conflict, some authority determines which is likely to render the greater public service. This then becomes the paramount use on the area in question; other uses are secondary, and, if they interfere seriously with the primary use, they are altogether excluded from the area. This policy is so obvious, simple, and practical that it needs no defense.

Moreover this policy need not be changed, in the slightest when recreation comes to be recognized in the list of major utilities. It is, in fact, the policy already and inevitably adopted. On the principal areas of the National Forests recreation is an incidental use; on some it is a paramount use; on a fere it becomes the exclusive use.

With respect to this matter as it affects the internal workings of the Forest Service alone, some emphasis should be placed on the fact, frequently not recognized, that the recreation use on Forest lands only rarely interferes with other uses. In general the natural development and protection of the Forests operates directly to enhance the recreation values. On the other hand recreation, except where it becomes intensive at certain points, seldom infringes upon other uses of the Forest. The development of this fact has been, in some cases, rather surprising. For example, it has been found, contrary to common expectation, that the presence of campers and summer-home permittees in considerable numbers, instead of increasing the fire risk has in some cases actually assisted in fire protection. Any general argument therefore which alleges a conflict between the recreation uses and other Forest utilities starts from a premise which is not true. 
In any study of public recreation on the National Forests cne can not go very far without facing problems which lead beyond

Extra-departmental Aspects the confines of the Forest Service. Especially must consideration be given to possible interrelations with the National Park Service,

a separate branch of the Federal organization designed specifically to care for the larger enterprises of recreation on public lands dedicated to such use. It has been suggested that the existence of a National Park Service made it unnecessary and unwise for the Forest Service to concern itself at all with such matters.

As soon as any attempt is made to bring such theoretical suggestions down to a practical working basis they take form in one or the other of the following schemes: Either to turn over to the Park Service all recreational activities wherever located, or to transfer all recreation areas bodily from the National Forests to the National Parks. These two schemes are equally impossible, but on account of their frequent reappearance their unworkableness should be briefly exhibited.

The former plan would require the Forest Service and the Park Service to operate jointly in the same territory; and while such cooperation might conceivably be established in a few carefully delimited territories, it is altogether out of reason to expect such a dual administration to succeed over the enormous and far-flung areas of the National Forests and National Parks. The suggestion indeed proceeds on the assumption that only a few restricted portions of the Forests are used for recreation. This assumption is very far from the truth. The fact is, as already pointed out, that public recreation develops upon practically every square mile of the Forest domain. Such an interpenetration of two branches of administration (which now exist in two separate executive departments) could be accomplished only by the practical ama!- 
gamation of the two services. It would be practically necessary to consolidate the Forest Service and the Park Service into one administration under a single head.

The other alternative of transferring all recreation areas to the National Parks would simply abolish the National Forests. For as long as any Forests are left they will continue to be used for purposes of recreation; and these uses will be extensive and valuable.

While both these ideas are manifestly absurd when offered for sweeping adoption, each has some merit when applied within important limitations. Some degree of cooperation has naturally, almost necessarily, been established between the Forest Service and the Park Service, for example in the fire patrol of neighboring areas. Arrangements might be made, and obviously should be made, for connecting Park trails with Forest trails where the two services administer adjoining lands. Mention has already been made (p. 7) of the "Park-to-Park Highway" built through the National Forests and connecting Yellowstone and Glacier National Parks. Rather extensive timber cuttings for forest improvement and fire protection are needed at the present moment in certain places in the National Parks, and such operations could probably be conducted most advantageously by experienced men from the staff of the Forest Service. Cooperation in these and similar ways is much to be encouraged; but all this falls far short of the wholesale exchange of services imagined by those who would offer this as a complete solution of all administrative problems.

The second suggestion, that recreation areas be taken out of the National Forests and added to the National Parks is also capable of limited application. It has in fact been adopted in the case of Glacier and Rocky Mountain National Parks; and the move to assign the Grand Canyon to the family of the National Parks is approved by all informed persons. 


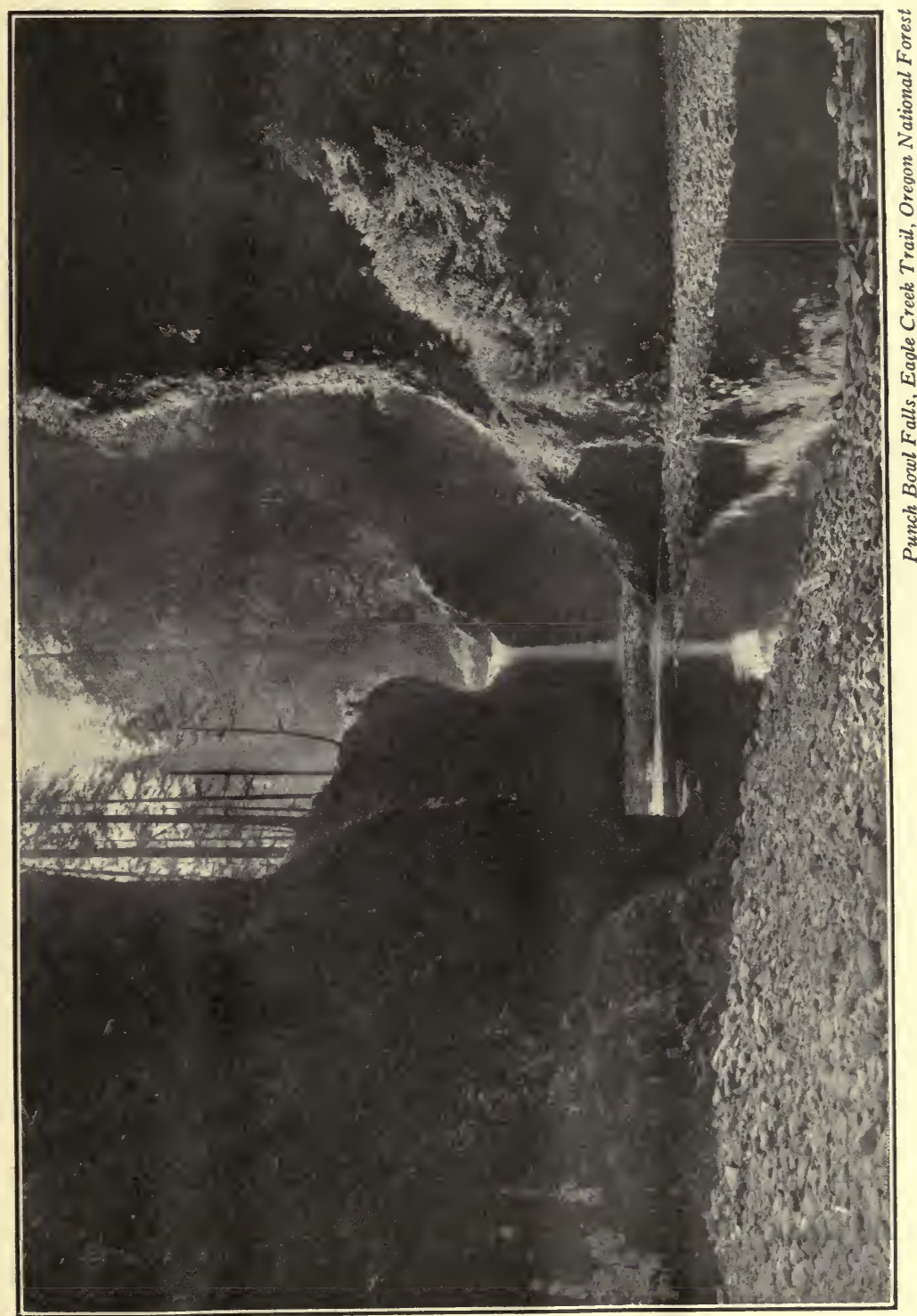




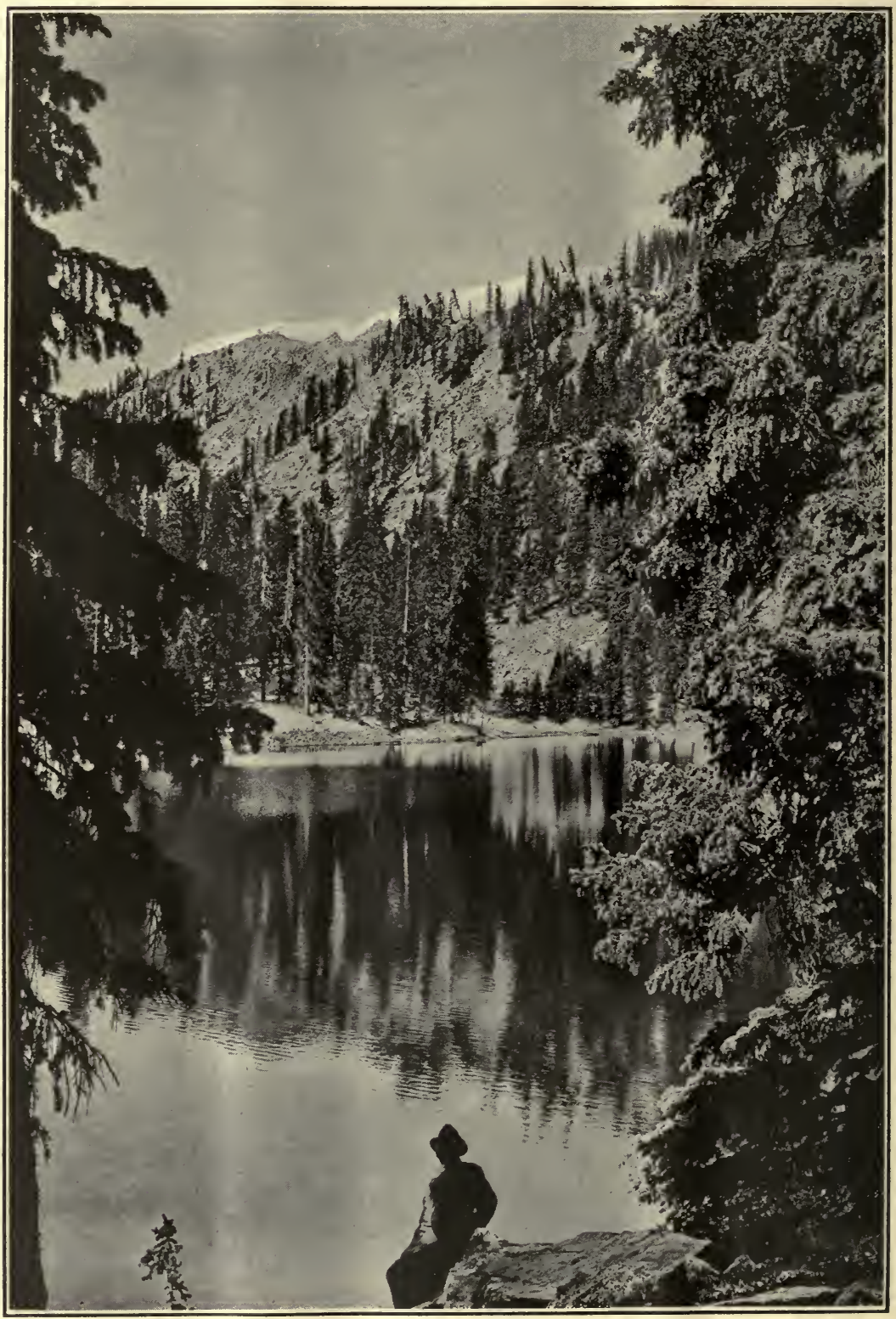

Santa Fe Lake, Santa Fe National Forest 
But any general movement in this direction faces serious perils. At the present moment there are being pushed a dozen or more ill-considered schemes to establish "National Parks," which parks would be obviously in no sense national except that Uncle Sam might foot the bills. The plain intent of some of these proposals is to appropriate the advertising value of the National Park name for the benefit of some city or local community. Against all such schemes it is necessary in the public interest to make the strongest stand. Were such a policy to be followed the result would be a serious menace both to the National Forests and to the National Parks. The Forests would suffer through the alienation of important areas and the disturbance of Forest administration. The Parks would suffer through the degradation of their present high reputation.

To anyone who examines the facts at any length in their practical bearings it soon becomes evident that special areas can not be arbitrarily transferred from the National Forests just because they happen to bẽ used for recreation. Even areas on which recreation comes to be the exclusive use can not always, or even generally, be segregated in this manner. As a striking example of this principle the White Mountain Forest of New Hampshire may be cited. The White Mountain territory is peculiarly suited to recreation of many kinds. It is largely and intensively used for these purposes. It would be very easy for the theorist to say that this section is worth much more for its beauty than for its timber and that therefore it must be a Park instead of a Forest; yet the history of the region and of the legislation establishing the present National Forest are such as positively to require the continuance of the Forest administration.

Under such circumstances it is idle and mischievous to talk about the suppression of recreation activities on the National Forests, or of divesting the Forest Service of the administration of recreation uses, or of any other policy than a clear-cut, straight- 
forward development of recreation utilities on their merits and by the best known means.

The inevitable conclusion from these considerations is that the Park Service be entrusted with the care of large and important areas where the preservation of unique landscape values is of paramount importance and where recreation is the exclusive utility; but that areas in which several utilities, including recreation, are to be administered should properly be assigned to the charge of the Forest Service. Such a policy would be intelligible and practical, and can be carried out by the organizations now in the field.

Within the Forest Service organization another serious problem now emerges. As soon as it becomes clear that recreation is an important and a permanent utility upon the A Perennial Forests and that it must be administered on Problem its merits in fair comparison with timber production, watershed protection, grazing and other utilities, it becomes clearly necessary to provide the methods whereby the varying (and sometimes conflicting) claims of these several utilities may be adjudicated. The Forest Service has already developed intensive studies in land classification which lead in this direction. This classification of lands as to their uses may easily be carried farther and may be made to include a consideration of recreation values.

But conditions change from year to year. An adjustment which is fair to all interests now may not be wisest under the new conditions so years hence. We seek a moving equilibrium. In short, the Forest Service needs, within its own organization, a committee on forest utilities which shall constantly endeavor to secure the fullest development of all the resources in the National Forests. Before this committee all questions of recreation uses, landscape protection, and their like will be determined in fair 
comparison with other utilities. Such a committee would be able to decide with respect to each unit of the Forest areas the extent to which recreation might be permitted or encouraged, whether it should be subordinate or paramount to grazing, timber production, or watershed protection, and what assignment of responsibility within the Service personnel would best meet the needs of the area as weighed by the committee.

Plainly such a committee should include some one with a liberal and sympathetic knowledge of recreation and landscape values, just as it would need men well informed as to timber valuesand grazing values. Some such competent court is actually necessary to the just development of recreation utilities on the National Forests. Steps have already been taken to extend the work in land classification so as to meet these requirements.

It has always been the policy of the Forest Service to employ men of special technical ability on the numerous problems arising

Specially

Trained Men Needed in the management of the Forests. Thus men trained in technical forestry are placed in charge of sylvicultural operations, men expert in the cattle industry control questions of grazing; while mining engineers, land surveyors, lawyers, entolmologists, and statisticians are employed for those investigations, operations, and lines of administration in which they are severally experienced. A considerable part of the success achieved by the Forest Service has unquestionably been due to this policy.

When we come now to recognize recreation as an essential and inescapable Forest utility we can not be blind to the need of specialized service of another kind. It will be seen that the undertakings actually in hand as enumerated in earlier sections of this pamphlet (viz, trail location, planning and equipment of automobile camps, picnic grounds, protection and development of scenic reservations, game preservation, recreation activities in National 
Monuments, the layout of permanent camp areas, the planning of permanent communities, etc.) fall most nearly within the field of the landscape engineer. A somewhat specialized kind of landscape engineering is in fact needed upon these Forest problems, but in a general way the professional training actually available in landscape engineering best meets the special requirements here developing.

The principal conclusions reached in the foregoing discussion may be briefly summarized as follows:

\section{General Summary}

I. The National Forests cover wide areas of land, much of it wild, interesting, and beautiful in a surpassing degree. The total area is approximately $156,000,000$ acres, equal to about three and one-half times the whole of New England, or to the combined States of Louisiana, Alabama, Florida, Georgia, and Mississippi; or to the great block of Central States, Iowa, Missouri, Illinois, Indiana, and Ohio. These Forests are distributed through 22 States and Territories.

2. Historically it appears that National Forests were first created for purposes of recreation, and that this use is traditionally universal.

3. Actually it appears that the National Forests of the United States have always been extensively used for recreation and that these uses are rapidly increasing.

4. The principal forms of recreation now in vogue are hunting, fishing, hiking, packing, camping, automobiling, and picnicking.

5. The construction and general supervision of permanent camps, picnic grounds, playgrounds, and town sites has become clearly necessary in the public interest.

6. Game preservation has already been recognized as a legitimate and worth-while feature of Forest administration. 
7. The protection of particularly good scenery and of relics of historic or archæological value is also recognized as a proper function of Forest Service administration.

8. Several National Monuments assigned to the care of the Forest Service are maintained mainly for recreational purposes and for purposes of study.

9. The extent to which the Forest areas are already being used for recreation is remarkable. It appears that about 3,000,000 persons annually visit the Forests for recreation, and that their number is rapidly increasing. It is estimated that the average stay of these visitors is two and one-half days.

Io. A cash valuation may be reasonably placed on this body of recreation. According to the lowest possible estimates it would have a commercial value of $\$ 7,500,000$ annually.

II. At all events it seems obvious that recreation must be recognized as a large and highly valuable utility in the National Forests, and that this utility must be fairly conserved and developed in proportion to its value to the public.

12. To this end the Forest Service should undertake to make a study of general recreation policies and of the specific requirements of specific areas within the National Forests, so as to arrive at a correct estimate of recreation values and to provide the best means of developing and administering these utilities.

13. In this work the Forest Service should employ men suitably trained and experienced in recreation, landscape engineering, and related subjects. 


\section{Appendix I}

\section{The National Forests}

\begin{tabular}{|c|c|c|c|c|c|}
\hline $\begin{array}{c}\text { State in which } \\
\text { located. }\end{array}$ & Forest. & Area. & $\begin{array}{c}\text { State in which } \\
\text { located. }\end{array}$ & Forest. & Area. \\
\hline \multirow{3}{*}{ Alaska.......... } & & & & & \\
\hline & Chugach.......... & $.5,418,659$ & Colorado.... & Leadville..... & 934, ox 7 \\
\hline & Tongass........... & $15,451,716$ & & Montezuma. . & 700,082 \\
\hline \multirow[t]{10}{*}{ Arizona .......... } & Apache...... & $\mathrm{I}, \mathrm{I} 82,782$ & & Pike......... & $\mathrm{I}, 080,38 \mathrm{I}$ \\
\hline & Coconino.... & I, 601,598 & & Rio Grande. . & I, I36, 884 \\
\hline & Coronado $a \ldots$ & $\mathrm{I}, 307,46 \mathrm{x}$ & & Routt....... & 833,459 \\
\hline & Crook......... & 870,130 & & San Isabel. . . & 598,912 \\
\hline & Dixie $a \ldots$ & $I_{7}, 680$ & & San Juan....... & 617,995 \\
\hline & Kaibab... & $\mathbf{x}, 072,900$ & & Sopris .......... & 596,986 \\
\hline & Prescott... & I, 433,366 & . & Uncompahgre... & 790,349 \\
\hline & Sitgreaves.. & 659,337 & & White River.... & 848 , or 8 \\
\hline & Tonto...... & I, 994,239 & Florida. . & Florida........ & 308,268 \\
\hline & Tusayan.... & $x, 602,750$ & Idaho... . & Boise...... & $\mathrm{I}, 058,94 \mathrm{I}$ \\
\hline \multirow[t]{2}{*}{ Arkansas.......... } & Arkansas.... & 626,746 & & Cache $a . . .$. & $49^{2}, 668$ \\
\hline & Ozark....... & 291,840 & & Caribou $a \ldots$ & $68 \mathrm{I}, 540$ \\
\hline \multirow[t]{20}{*}{ California.......... } & Angeles.... & 820,980 & & Challis..... & $\mathrm{I}, 259,237$ \\
\hline & California... & 807,444 & & Clearwater........ & 785,103 \\
\hline & Cleveland... & $547,98 \mathrm{I}$ & . & Coeur d'Alene..... & $662,6 \mathrm{II}$ \\
\hline & Crater $a . .$. & 46,977 & & Idaho......... & I, 193,439 \\
\hline & Eldorado $\dot{a}$ & 549,392 & & Kaniksu $a \ldots$ & I98, 757 \\
\hline & Inyo $a \ldots . .$. & $I, 269,980$ & & Lemhi....... & $I, \propto 95,924$ \\
\hline & Klamath $a$. & $\mathrm{I}, 470,84 \mathrm{I}$ & & Minidoka $a$. & 509,536 \\
\hline & Lassen .... . & 936,877 & & Nezperce... & $\mathrm{I}, 624,5^{82}$ \\
\hline & Modoc.... & I, 182,986 & & Payette..... & 831,926 \\
\hline & Monoa..... & $784 \cdot \epsilon_{20}$ & & Pend Oreille. & $676, \mathrm{OI}_{4}$ \\
\hline & Monterey . . & 316,058 & & St. Joe....... & 493,925 \\
\hline & Plumas....... & $\mathrm{I}, \mathrm{I} 4 /_{\mathrm{r}}, 835$ & & Salmon..... & $1,621,707$ \\
\hline & Santa Barbara. & $\mathrm{I}, 688,57 \mathrm{I}$ & & Sawtuoth... & $\mathrm{I}, 203,387$ \\
\hline & Sequoia....... & I $, 882,980$ & & Selway..... & I. $693,7 \mathrm{II}$ \\
\hline & Shasta... & $80_{3}, 448$ & & Targhee $a . .$. & 977,847 \\
\hline & Sierra.... & $7,489,934$ & & Weiser..... & 562,609 \\
\hline & Siskiyou $a$. . & 349,069 & Michigan....... & Michigan.... & 89,466 \\
\hline & Stanislaus. . & 810,399 & Minnesota... & Minnesota... & 190,602 \\
\hline & Tahoe $a \ldots$ & 542,226 & & Superior... . & 857,255 \\
\hline & Trinity.. & $\mathrm{I}, 430,547$ & Montana... & Absaroka... & 842,467 \\
\hline \multirow[t]{9}{*}{ Colorado.......... } & Arapaho... & 634,903 & & Beartooth... & 662,537 \\
\hline & Battlement. & 651,227 & & Beaverhead. & $I, 337,223$ \\
\hline & Cochetopa... & 905,723 & & Bitterroot... & I, 047,012 \\
\hline & Colorado.... & 847,328 & & Blackfeet... & 865,077 \\
\hline & Durango... & 614,129 & & Cabinet.... & 830,676 \\
\hline & Gunnison. . & 908,055 & & Custer..... . & 428,922 \\
\hline & Hayden $a$. & 65,598 & & Deerlodge... & $833, x_{7} 8$ \\
\hline & Holy Cross....... & 576,905 & & Flathead.... & $1,802,905$ \\
\hline & La Sal $a \ldots \ldots \ldots$ & 27,444 & & Gallatin.......... & 564,855 \\
\hline
\end{tabular}

a Part-Area of Forest in more than one State. 
The National Forests-Continued

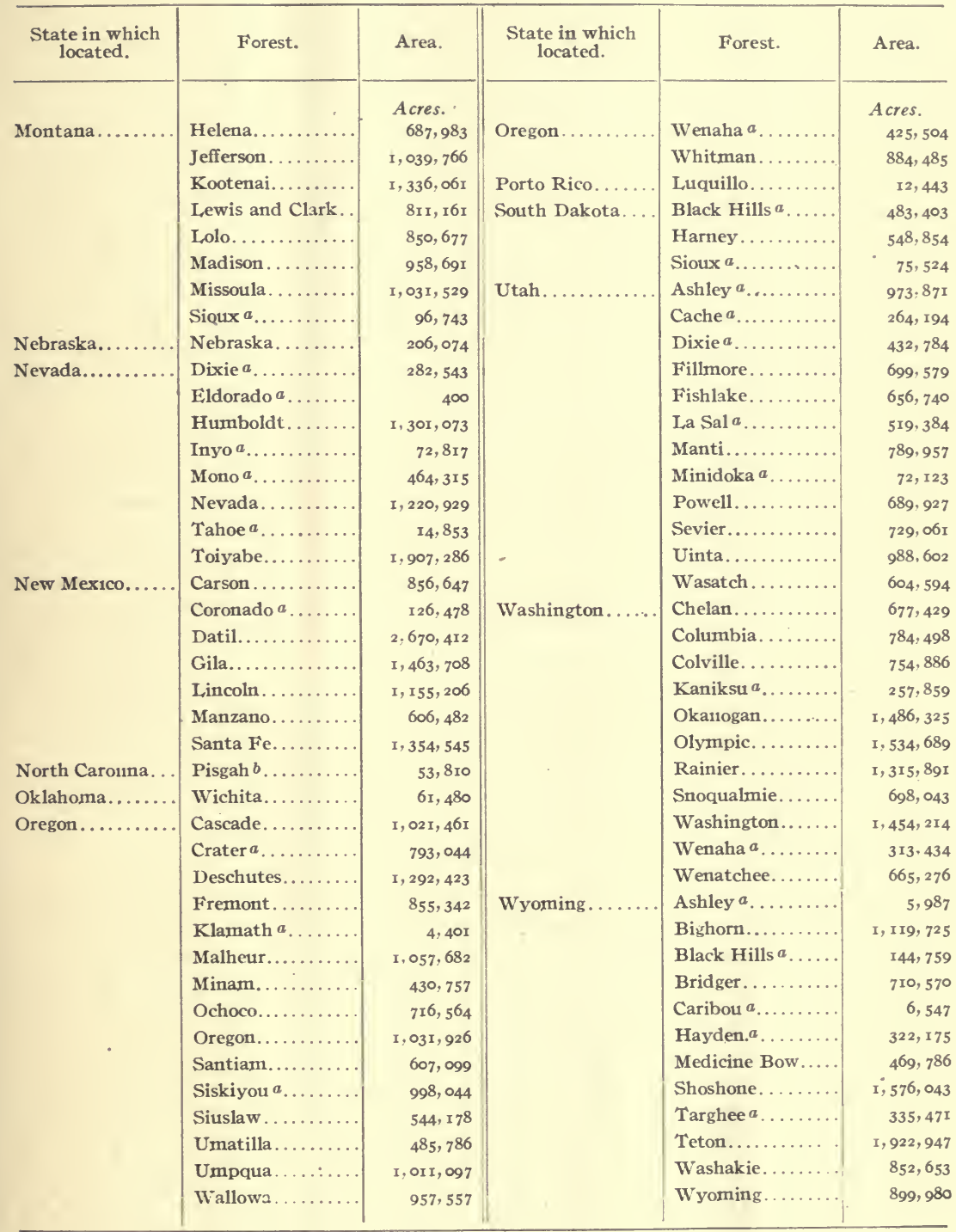

a Part-Area of Forest in more than one State.

$b$ Area acquired under the Weeks law. 


\section{Lands Acquired Under the Weeks Law}

To January 1, 1918

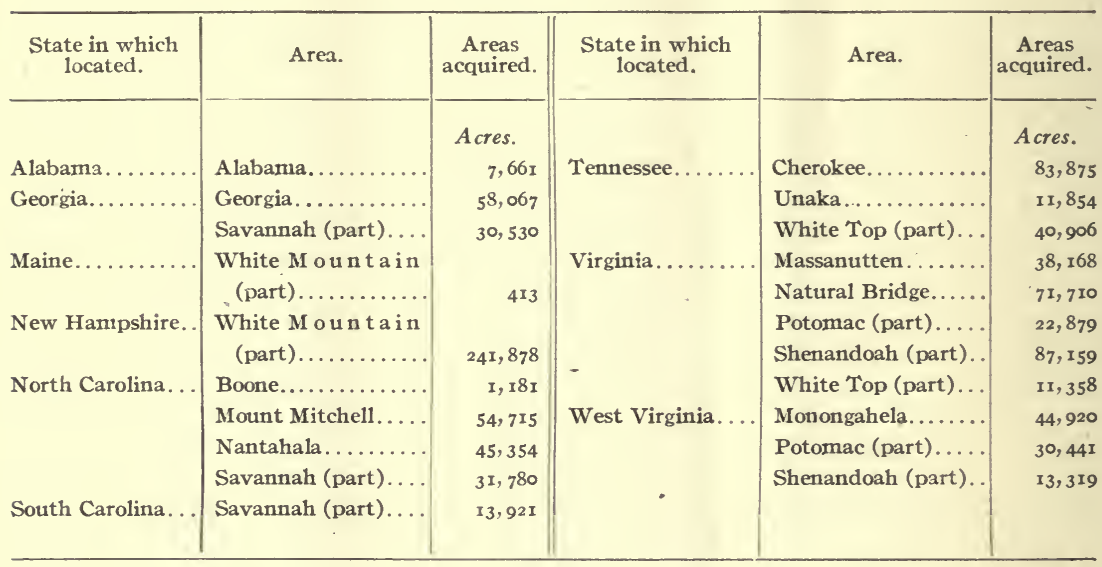




\section{Appendix II}

\section{National Game Preserves}

The following national preserves situated wholly or in part within National Forests have been designated under special acts of Congress for the protection of game:

\begin{tabular}{|c|c|c|c|c|c|}
\hline Name. & National Forest. & State. & Act approved. & $\begin{array}{l}\text { Latest proc- } \\
\text { lamation. }\end{array}$ & Area. \\
\hline Grand Canyon.. & $\begin{array}{l}\text { Tusayan..... } \\
\text { Kaibab...... }\end{array}$ & Arizona... & $\left\{\begin{array}{l}\text { June } 29,1906 \\
\left(\mathrm{~S}_{34} \text { tat., } 607 .\right)\end{array}\right.$ & June & $\begin{array}{l}\text { Acres. } \\
\text { I, 492, } 928\end{array}$ \\
\hline Pisgah.... & Pisgah............ & North Carolina... & $\begin{array}{l}\text { Mar. I, I9II } \\
\text { (36Stat., 96I.) }\end{array}$ & Oct. 17,1916 & 53,810 \\
\hline Wichita........ & Wichita... & Oklahoma.......... & $\begin{array}{l}\text { Jan. } 24,1905 \\
\text { (33. Stat., 614.) }\end{array}$ & $\begin{array}{c}\text { June } \quad 2,1905 \\
.\end{array}$ & 57,120 \\
\hline
\end{tabular}




\section{Appendix III}

\section{National Monuments within National Forests}

I. Bandelier National Monument, in the Santa Fe Forest, New Mexico; area, 22,075 acres; created to preserve prehistoric aboriginal ruins.

2. Devil's Post Pile, in the Sierra National Forest, California; area, 800 acres; created to reserve lands of scientific interest due to the existence of lava field, etc., and as an illustration of volcanic activities.

3. Gila Cliff Indian Dwellings in the Gila National Forest in New Mexico; area, I60 acres. The Gila Hot Springs Cliff Houses are the best representative of cliff dwellers' remains in that region.

4. Grand Canyon 'National Monument, in Arizona, made from Kaibab and Tusayan National Forests; area, 8c6,400 acres. This is the greatest eroded canyon in the United States.

5. Jewel Cave, in the Black Hills Forest in South Dakota; area, I,280 acres. Natural formation consisting of a cave of great scientific and public interest.

6. Mount Olympus National Monument, in the Olympic National Forest, Washington; area, 299,370 acres. This reserves certain lands containing objects of unusual scientific interest, including numerous glaciers; the region has formed a summer range and breeding ground for the Olympic elk, a peculiar species rapidly decreasing in numbers.

7. Old Kassaan, in the Tongass, Alaska; area, 38 acres; for the preservation of certain aboriginal ruins of the former Haida Indian village, representing a distinctive type of aboriginal American civilization.

8. Oregon Caves, in the Siskiyou Forest, Oregon; area, 480 acres. These are natural caves of unusual scientific interest and importance. 
9. Tonto National Monument, in the Tonto Forest, Arizona; area, 640 acres. Two prehistoric ruins of ancient cliff dwellings of ethnologic, scientific, and educational interest.

Io. Walnut Canyon, in the Coconino National Forest, Arizona; area, 966 acres. Prehistoric ruins of cliff dwellings of great educational and scientific interest.

I I. Wheeler National Monument, in the Rio Grande Forest, Colorado; area, 300 acres. Certain volcanic formations of unusual interest as illustrating erratic erosion. 



\section{Manufaclurers}

Syracuse, N. Y.

Stockten, Calif. 
$\therefore 0$ 